\title{
Inactivation of Rubella Virus by Gamma Radiation
}

\author{
M. T. KENNY, K. L. ALBRIGHT, J. B. EMERY, AND J. L. BITTLE \\ Department of Infectious Diseases, The Dow Chemical Company, Human Health Research and \\ Development Laboratories, Zionsville, Indiana 46077
}

Received for publication 24 July 1969

\begin{abstract}
The Gilchrist and M-33 strains of rubella virus exposed in the frozen state to ${ }^{187} \mathrm{Ce}$ or ${ }^{60} \mathrm{Co}$ were inactivated exponentially according to "one hit" kinetics. There was no difference in the radiosensitivity of the two strains. Experimental $D_{37}$ values for both strains ranged from $1.9 \times 10^{5}$ to $2.9 \times 10^{5}$ rads, and computed radiosensitive molecular weights ranged from $2.6 \times 10^{6}$ to $4.0 \times 10^{6}$ daltons.
\end{abstract}

Gamma radiation has been used successfully to study the physical, chemical, and biological properties of a number of viruses $(1,3,4,9)$, and data from many of these studies correlate well with data obtained by other methods $(5,6,13)$. In the study reported here, gamma radiation was used to study the inactivation kinetics of rubella virus irradiated under conditions minimizing indirect radiation effects. $D_{37}$ (dose giving $37 \%$ survival) values obtained from this study were used to determine the radiosensitive molecular weight of the rubella virion.

\section{MATERIALS AND METHODS}

Virus strains. The Gilchrist strain of rubella virus was received from D. A. Fuccillo, National Institute of Neurological Diseases and Blindness, after 13 passages in primary Cercopithecus monkey kidney (PCMK) tissue culture at $35 \mathrm{C}$. Virus in the 15th to the 20th PCMK passage levels was used in this study. The M-33 strain of rubella virus was received from P. D. Parkman, Division of Biologics Standards, National Institutes of Health, after 19 passages in PCMK tissue culture at $35 \mathrm{C}$ and was used in the 26th and 27th passage levels for irradiation studies.

The 22nd PCMK passage level of the M-33 strain was adapted to growth in BHK-21 cells by six serial passages in these cells at $35 \mathrm{C}$. The BHK-21-adapted Gilchrist strain was received from G. L. Gitnick, National Institute of Neurological Diseases and Blindness.

Virus propagation. PCMK Blake bottle cultures containing complete monolayers were overlayed with $10 \mathrm{ml}$ of rubella virus $\left(5,000\right.$ to $\left.8,000 \mathrm{mD}_{50}\right)$. After an adsorption period of $2 \mathrm{hr}$ at $35 \mathrm{C}, 90 \mathrm{ml}$ of medium 199 containing $0.11 \%$ bicarbonate, $2 \%$ fetal calf serum (FCS), and $100 \mu \mathrm{g}$ of streptomycin and $100 \mu \mathrm{g}$ neomycin per $\mathrm{ml}$ was added to each bottle, and the cultures were incubated at $35 \mathrm{C}$. At 7 days, the monolayers were washed with $100 \mathrm{ml}$ of serum-free medium $199 ; 100 \mathrm{ml}$ of fresh medium 199 containing $0.5 \%$ human plasma albumin (HPA; Calbiochem, Los Angeles, Calif., or The Dow Chemical Co., Indianapolis, Ind.) instead of FCS was added to the cultures. Cultures were harvested by complete medium change three times per week until the cultures degenerated. Harvested fluids were stabilized by an additional $0.5 \%$ HPA and clarified by centrifugation at $4 \mathrm{C}$ for $30 \mathrm{~min}$ at $800 \times \mathrm{g}$. Clarified fluids were stored at $-55 \mathrm{C}$ until they were divided for irradiation. Some pools were also prepared in albumin-free medium 199.

BHK-21 Spinner cultures were prepared by seeding culture vessels simultaneously with 100 to $200 \mathrm{ml}$ of cell suspension adjusted to contain $1.0 \times 10^{6}$ viable cells per ml and rubella virus at an imput ratio of 0.003. The Spinner medium employed was that described by Vaheri et al. (16), except that $100 \mu \mathrm{g}$ of neomycin per $\mathrm{ml}$ was substituted for nystatin. Cultures were harvested at 2- to 3-day intervals by removing one-half of the culture medium and replacing it with an equal volume of fresh medium. Harvested fluids were frozen and thawed to disrupt the cells, and were then centrifuged at $4 \mathrm{C}$ for $30 \mathrm{~min}$ at $800 \times g$ to remove the debris. Clarified fluids were stored at $-55 \mathrm{C}$ until they were divided for irradiation.

Virus irradiation. Rubella virus suspensions, supplemented with various additives, were plug-frozen in alcohol-dry ice in screw capped tubes $(20 \times 125 \mathrm{~mm})$, $15 \mathrm{ml}$ of virus suspension per tube. The additives employed were HPA, agamma calf serum, L-histadine (L-HIS), L-methionine (L-MET), and L-cysteine (L-CYS). The samples were gamma-irradiated in dry ice (to minimize indirect radiation effects) by exposure to cobalt 60 or cesium 137 at a dose rate of 62 to 1,614 $\mathrm{krads} / \mathrm{hr}$. Samples received total dosages ranging from $2.5 \times 10^{5}$ to $4.5 \times 10^{6}$ rads. Radiation dosimetry was calculated by the ferrous-ferric sulfate system (5).

Determination of inactivation kinetics. Residual live rubella virus in irradiated preparations was measured by the interference technique (12) in PCMK tube cultures. Serial 10-fold dilutions of virus irradiated at each dose level were prepared in Eagle basal medium with Earle salts supplemented with $2 \%$ FCS and $30 \mu \mathrm{g}$ of erythromycin, $25 \mu \mathrm{g}$ of aureomycin, $100 \mu \mathrm{g}$ of streptomycin, 100 units of polymixin B, and $5 \mu \mathrm{g}$ of amphotericin B per $\mathrm{ml}$ (BME-E maintenance medium). A 0.2-ml amount of 
each dilution was inoculated into a total of 20 to 25 PCMK cultures from which the medium had been removed. After an adsorption period of $2 \mathrm{hr}$ at $35 \mathrm{C}$, $1.8 \mathrm{ml}$ of BME-E maintenance medium was added to each tube, and the cultures were incubated at $35 \mathrm{C}$ in the stationary position. The medium was changed at 7 days, and the cultures were challenged at 8 to 11 days with approximately 1,000 TCID $_{50}$ coxsackie A-9 virus. Unirradiated virus controls were tested in a similar manner. A standard rubella virus preparation (M-33 strain) was assayed in each lot of cells employed to determine the relative sensitivity of the cells for rubella virus. Titers were plotted as percentage of survival on semilog paper, and $D_{n}$ values were read from the graph. Radiosensitive molecular weights were calculated by the method described by Ginoza (5).

\section{RESULTS}

Inactivation kinetics. Figures 1 and 2 show that exposure of the Gilchrist and M-33 strains of rubella virus to gamma radiation results in an exponential decay of virus infectivity. This indicates that the virus preparations were homogeneous with respect to radiation sensitivity. Examination of $D_{37}$ values (Table 1) shows that there was little difference in the radiation sensitivity of the Gilchrist strain when irradiated in the presence of medium 199 or medium 199 containing $1 \%$ HPA, $1 \%$ HPA plus $0.2 \%$ L-HIS, or $1 \%$ HPA plus $0.2 \%$ L-MET. Addition of $0.2 \%$ L-CYS to the irradiation medium decreased the radiation sensitivity of the virus preparations. Figure 2 also shows that there is no significant difference in the rate of inactivation of the Gilchrist and M-33 strains propagated in PCMK cells and irradiated in the presence of medium 199 containing $1 \%$ HPA. Similar curves were obtained for both strains when propagated in BHK-21 cells and irradiated in the presence of BHK-21 Spinner medium. In addition, it was found that the tissue substrate used for virus propagation had little effect on the radiation sensitivity of a given strain. Thus, the $D_{37}$ value for the M-33 strain propagated in the PCMK cells was $2.0 \times 10^{5}$ rads and was $1.9 \times 10^{5}$ rads when propagated in BHK-21 cells (Table 1).

Radiosensitive molecular weights. Radiosensitive molecular weights computed from experimental $D_{37}$ values ranged from $1.9 \times 10^{6}$ to $3.3 \times$ $10^{6}$ daltons for the Gilchrist strain and from $3.8 \times 10^{6}$ to $4.0 \times 10^{6}$ daltons for the M-33 strain (Table 1). Excluding the low value obtained for virus irradiated in the presence of the radioprotective substance L-CYS, the overall range in radiosensitive molecular weight for both strains was $2.6 \times 10^{6}$ to $4.0 \times 10^{6}$ daltons.

\section{DISCUSSION}

Rubella virus gamma-irradiated under conditions minimizing indirect radiation effects is

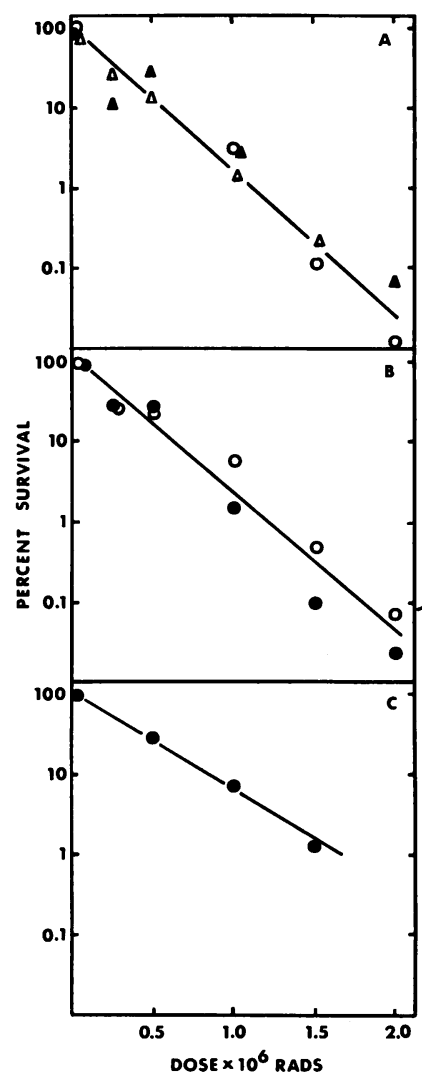

FIG. 1. Inactivation of PCMK-propagated rubella virus (Gilchrist strain) by gamma radiation in the presence of various substrates. (A) Medium 199 (M-199) containing 5\% agamma calf serum (O), $1 \%$ human plasma albumin $(H P A)(\triangle)$, and $1 \%$ HPA plus $0.2 \%$ L-methionine (A); (B) $M-199$ (O) and M-199 containing $1 \%$ HPA plus $0.2 \%$ L-histadine (O); (C) M-199 containing $0.2 \%$ L-cysteine (O).

inactivated exponentially according to "one hit" kinetics. These data are consistent with those shown for other viruses after gamma irradiation, including polyoma $(1,9)$, foot-and-mouth disease (13), Venezuelan equine encephalitis (15), vaccinia, St. Louis encephalitis, Western equine encephalitis, and polioviruses (8), SV-40 and adenovirus type 7 (4), influenza A (14), and for a cabbage looper nuclear polyhedrosis virus (7).

Inclusion of the sulfydryl compound L-cysteine to the irradiation medium protected the virus against radiation damage as indicated by a reduction in the slope of the inactivation curve. This modification of direct radiation effect has also been observed after X-ray irradiation of tobacco mosaic virus in the presence of reduced glutathione (6) and has been attributed to intermolecular energy transfer (5). No such effect was observed when the sulfur-containing 
TABLE 1. $D_{37}$ values and radiosensitive molecular weights of the $M-33$ and Gilchrist strains of rubella virus propagated in PCMK and BHK-21 cells

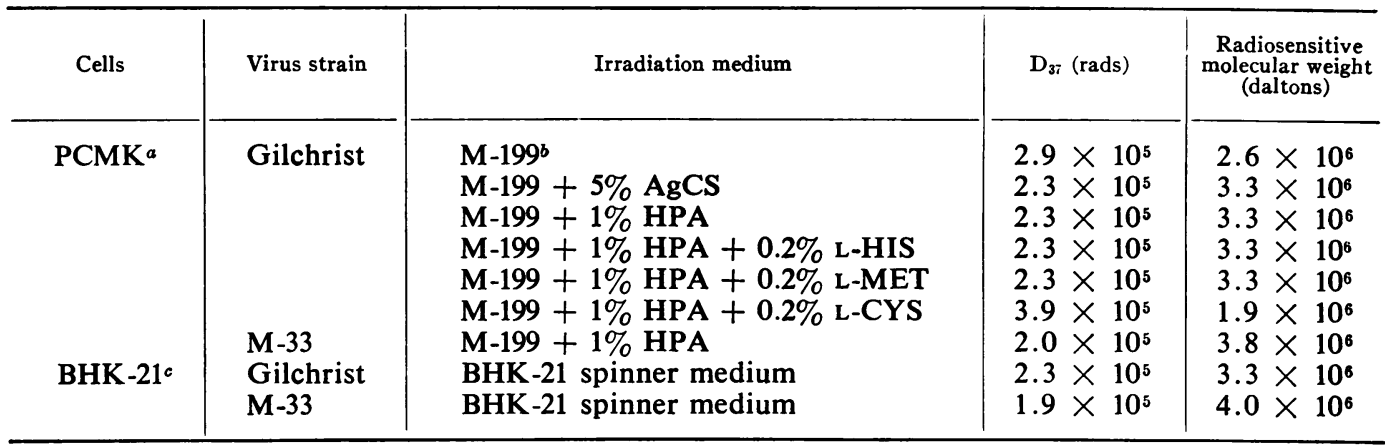

${ }^{a} \log _{10}, 3.0$ to $4.3 ; \mathrm{ID}_{50} / 0.2 \mathrm{ml}$; prior to irradiation.

b Abbreviations: M-199, medium 199; AgCS, agamma calf serum; HPA, human plasma albumin; L-HIS, L-histadine; L-MET, L-methionine; and L-CYS, L-cysteine.

c $\log _{10}, 4.3$ to $4.8 ; \mathrm{ID}_{50} / 0.2 \mathrm{ml}$; prior to irradiation.

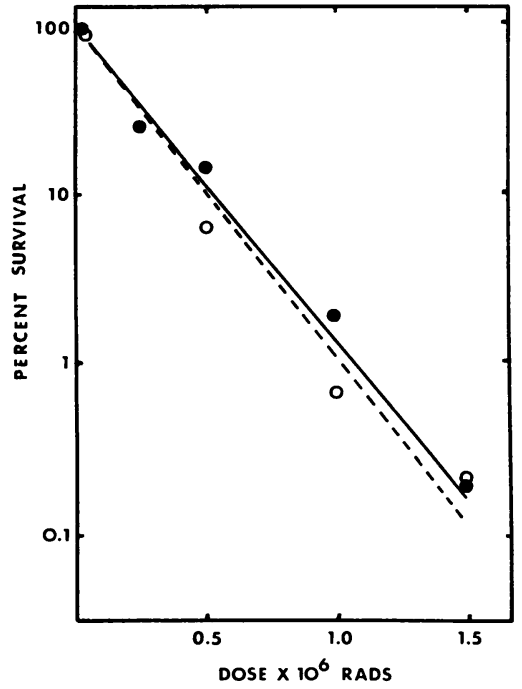

Fig. 2. Inactivation of PCMK-propagated Gilchrist (O) and $M-33(O)$ strains of rubella virus by gamma radiation in the presence of medium 199 containing $1 \%$ human plasma albumin.

amino acid L-methionine was included in the radiation medium. Polley (14) was able to show a reduction in the rate of influenza $A$ virus inactivation by gamma radiation in the presence of $0.2 \%$ L-histadine. These virus preparations, however, were irradiated in saline in the liquid state. Histadine does not produce this protective effect on rubella virus preparations irradiated under conditions minimizing indirect radiation effects.

Ginoza (5) showed that, when single-stranded ribonucleic and (RNA) or deoxyribonucleic acid viruses are irradiated under conditions selected to minimize indirect radiation effects, radiosensi- tive molecular weights closely approximate the molecular weights obtained for the nucleic acid moieties by physico-chemical methods. Several studies $(2,10,11)$ have shown that rubella virus contains RNA, and it is generally assumed that the molecule exists in the single-stranded form in the mature virion. Our studies have shown that the radiosensitive molecular weight for rubella virus ranges from $2.6 \times 10^{6}$ to $4.0 \times 10^{6}$ daltons. Physical-chemical data, however, are needed to confirm these findings.

\section{ACKNOWLEDGMENTS}

This study was supported by Public Health Service Contract no. PH 43-66-461.

We thank D. Harmer, Radiochemistry Research Laboratory, The Dow Chemical Co., Midland, Mich., for irradiation of the virus preparations. We also thank B. Bealmear and E. Kugel for their excellent technical assistance.

\section{LITERATURE CITED}

1. Basilico, C., and G. DiMayorca. 1965. Radiation target size of the lytic and the transforming ability of polyoma virus. Proc. Nat. Acad. Sci. U.S.A. 54:125-127.

2. Cusumano, C. L., G. M. Schiff, J. L. Sever, and R. J. Huebner. 1964. Rubella virus: nucleic acid studies using 5 iodo $2^{\prime}$. deoxyuridine. J. Pediat. 65:138-140.

3. Decker, C., J. Guir, and A. Kirn. 1969. Infectivity and capacity for DNA replication of vaccinia virus irradiated by $\gamma$-rays. J. Gen. Virol. 4:221-227.

4. Defendi, V., F. Jensen, and G. Sauer. 1967. Analysis of some viral functions related to neoplastic transformation, $p$. 645-662. In J. S. Colter and W. Paranchych (ed.), The molecular biology of viruses. Academic Press Inc., New York.

5. Ginoza, W. 1968. Inactivation of viruses by ionizing radiation and by heat, p. 139-209. In K. Maramorosch and $\mathbf{H}$. Koprowski (ed.), Methods in virology, vol. 4. Academic Press Inc., New York.

6. Ginoza, W., and A. Norman. 1957. Radiosensitive molecular weight of tobacco mosaic virus nucleic acid. Nature 179: 520-521.

7. Jaques, R. P. 1968. The inactivation of the nuclear Polyhedrosis virus of Trichopusia ni by gamma and ultraviolet radiation. Can. J. Microbiol. 14:1161-1163. 
8. Jordan, R. T., and L. L. Kempe. 1956. Inactivation of some animal viruses with gamma radiation from cobalt-60. Proc. Soc. Exp. Biol. Med. 91:212-215.

9. Latarjet, R., R. Cramer, and L. Montagnier. 1967. Inactivation by UV-, $X$-, and $\gamma$-radiations, of the infecting and transforming capacities of polyoma virus. Virology 33:104111.

10. Maassab, H. F., and K. W. Cochran. 1964. Influence of 5fluoro-deoxyuridine on growth characteristics of rubella virus. Proc. Soc. Exp. Biol. Med. 117:410-413.

11. Oxford, J. S., C. W. Potter, and R. N. P. Sutton. 1965. Determination of the type of nucleic acid in rubella virus using 5-bromo-2' -deoxyuridine. Nature 207:324-326.

12. Parkman, P. D., E. L. Buescher, M. S. Artenstein, J. M. McCown, F. K. Mundon, and A. D. Druzd. 1964. Studies of rubella. I. Properties of the virus. J. Immunol. 93:595607.

13. Polatnick, J., and H. L. Bachrach. 1968. Ionizing irradiation of foot-and-mouth disease virus and its ribonucleic acid. Arch. Gesamte Virusforsch. 23:96-104.

14. Polley, J. R. 1961. Factors influencing inactivation of infectivity and hemagglutinin of influenza virus by gamma radiation. Can. J. Microbiol. 7:535-541.

15. Reitman, M., and H. R. Tribble, Jr. 1967. Inactivation of Venezuelan equine encephalomyelitis virus by $\gamma$-radiation. Appl. Microbiol. 15:1456-1459.

16. Vaheri, A., W. D. Sedwick, and S. A. Plotkin. 1967. Growth of rubella virus in BHK21 Cells. 1. Production, assay, and adaptation of virus. Proc. Soc. Exp. Biol. Med. 125:10861092. 